\title{
Preparatory course market and access to higher education in
} Finland : pocketful or pockets-full-of money needed?

\section{Kosunen, Sonja}

Routledge

2018

Kosunen , S , Ahtiainen , H \& Töyrylä , M 2018 , Preparatory course market and access to higher education in Finland : pocketful or pockets-full-of money needed? in A Tarabini \& $N$ Ingram (eds), Educational Choices, Transitions and Aspirations in Europe : Systemic, Imstitutional adn Subjective Challenges . Routledge research in international and comparative education, Routledge, Abingdon, Oxon .

http://hdl.handle.net/10138/311760

acceptedVersion

Downloaded from Helda, University of Helsinki institutional repository.

This is an electronic reprint of the original article.

This reprint may differ from the original in pagination and typographic detail.

Please cite the original version. 


\title{
Preparatory course market and access to higher education in Finland
}

\section{Pocketful or pockets full of money needed?}

\author{
Kosunen, Sonja, Ahtiainen, Hanna and Töyrylä, Marju
}

\section{Introduction}

The Finnish field of higher education $(\mathrm{HE})$ is often considered very egalitarian in terms of access due to its tuition-free organisation, even though several studies show how the student population of the Finnish universities is socially biased (e.g. Nori, 2011; Kivinen et al., 2012), and that, especially to certain status disciplines (such as law and medicine), more students from higher-social-class backgrounds are admitted. The question of how the social background of the applicant and especially the possession and investment of economic capital functions in the admission process are underexplored areas of research. Mari Käyhkö (2017: 18) describes how the Nordic democratic ideal of equality simultaneously denies the existence of classdifferences, which leads to the fact that social class is not discussed, even if the differences are experienced. The question of social class in Finnish higher education requires more in-depth and detailed analysis, as there are expected socially biased outcomes of successful admission of the higher social classes to bachelor- and doctoral-level programmes (see Nori, 2011; Jauhiainen \& Nori, 2017).

As in other contexts (Reay, 2005; Reay et al., 2009), the working-class students also in Finland have been described as counteracting their families' educational culture and stepping aside from the working-class life course when attending higher education (Käyhkö, 2017). Officially the pathways to status disciplines in Finland are open to all due to tuition-free studies and selection based on meritocratic entrance examinations. However, what is a fairly under explored area is the actual processes and practices during the admissionprocess and the role of economic capital that might influence the choices and eventually the composition of admitted students in higher education institutions (HEIs) (analysis on admission-process in France see van Zanten, 2015). The critical question is to be raised when discussing the access to status disciplines in Finnish higher education: is the path currently de facto equally open to everyone regardless of their socio-economic background?

This article aims to unravel the under-discussed role of private economic capital and the embedded social inequalities in the admission process to the highly competitive status disciplines of law and medicine in Finland, which are the two disciplines with the most expensive (up to more than 6,000 euros) and long-lasting private preparatory courses (up to 9 months) (see Kosunen et al., 2015). By analysing applicant interviews (n = 17) from a Bourdieusian perspective (Bourdieu, 1984, 1985, 1996) during their preparation for the entrance 
examinations, we aim to investigate what is actually happening and how much economic, cultural and social capital (and their different transformations from one form to another, for example from economic to cultural capital) are invested in the admission process to these degree programmes. Almost all degree programmes in universities, especially in the most selective disciplines, apply entrance examinations to all their candidates. All our interviewees have participated in private tutoring when preparing for the examinations, that is attended preparatory courses as a part of their preparation for the entrance examinations of law and medicine at the universities. The other possibility apart from attending a private tutoring course is to prepare for the entrance examinations autonomously, as all the materials tested in the examination are publicly available, even if not free of charge in most cases.

Private tutoring in the form of preparatory courses aiming to prepare the candidates for the entrance examinations was established in its preliminary forms in the 1970s, and several enterprises are nowadays providing tuition-based tutoring and shadow education to applicants (Kosunen et al., 2015). Even if the studies investigating the preparatory courses in Finland are still few (e.g. ibid.; Räisänen et al., 2014; Kosunen \& Haltia, under review; Ahola et al., 2016; Ahtiainen, 2017; Töyrylä, 2017), the work around the topic has high academic as well as policy value, as it deals potentially with patterns of producing and reproducing social positions through occupying educational positions in elite disciplines via utilising economic capital. Preparatory courses have a dual and paradoxical role as formation outside the official education system: on the one hand, they might enhance the chances of getting admitted for the applicants with less inherited cultural capital (but sufficient economic capital); on the other hand, they might just as well, due to the high prices, create a new form of social (self-)exclusion of candidates, who lack economic resources. They cannot thus attend a preparatory course and thereby might not apply at all, as, in the competition with other applicants, they consider their chances insufficient without the support of private tutoring. This creates an interesting paradox in admissions to high-status disciplines in Finland, in which the HE system boasts of providing access to everyone regardless of their economic resources.

Our theoretical angle leans strongly on Pierre Bourdieu's theory of transformation and transmission of capital (Bourdieu, 1984; Bourdieu \& Passeron, 1990) and follows the lines of previous applications of it in studies around HE (Reay et al., 2005). We are especially interested in the ways of transforming economic and cultural capital into each other. First, we describe the context in which the preparatory course companies operate and in which the applicants buy their services; second, we present the data and the analytical toolkit of this study; and third, we discuss the socially constructed need for private tutoring in this transition, as well as the different forms of capital embedded in this process, with a special focus on economic capital. In the final section, we discuss the possible implications of our findings to the discussion around social justice in access to HE. 
Choice of higher education in Finland and the construction of shadow education: preparatory course markets

The Finnish higher education system officially comprises traditional universities and universities of applied sciences (Ministry of Education and Culture, 2016a), which have thus far been tuition-free to students who come from EU/EEA countries. The structure of the Finnish education system is further explained in Figure 1.

Figure 1. Schematic presentation of the Finish education system

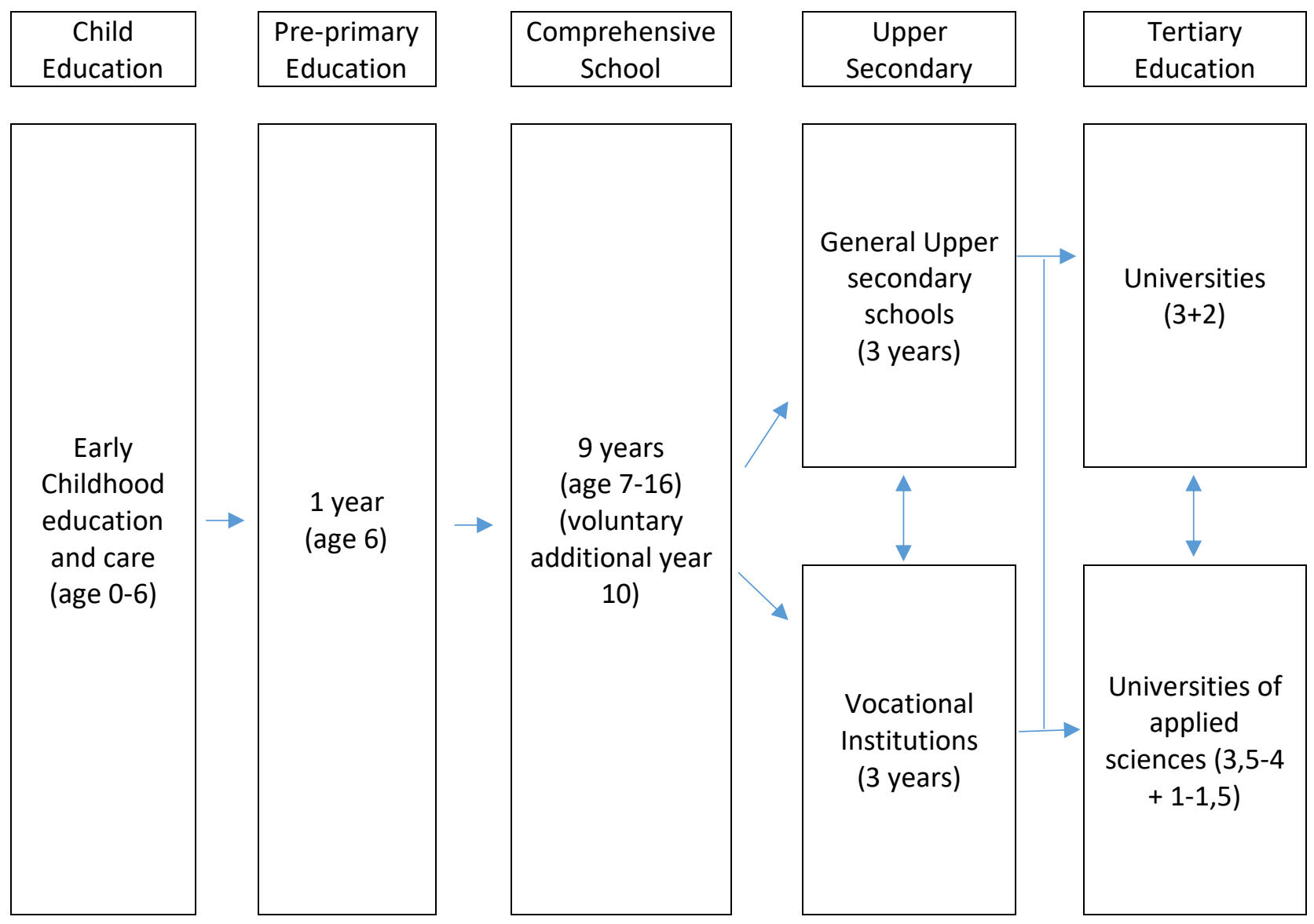

All students who have completed secondary education are officially eligible to apply for tertiary education. The selection of students in HE is based mainly on entrance examinations, which are organised by the respective universities and therefore institution and discipline centred. Historically (until the 20th century), higher education and education in general were seen as an upper class privilege in Finland (Ahola, 1995). Social class distinctions were strong, and university studies, in particular, were out of reach for the lower social classes. (Ahola, 1995: 35-36.) After industrialisation and urbanisation the changes in the society in general started to also show in education, as academic upper-secondary studies became more accessible and 
popular among the Finnish youth. The post-war population growth in the mid-1900s and the general change from an agricultural society towards an industrial and service-based economic structure raised the need of educating more people. It also made it possible to extend the education system both quantitatively and geographically. The increasing number of applicants and the pursuit of social equality led to a general growth of the Finnish field of higher education (Nevala, 1999): the massification of higher education emerged during the 1960s and 1970s. To control the expanded number of applicants in universities, numerus clausus method was implemented in all Finnish HEls in the 1960s (Ahola, 1995: 78), which meant that the number of university places was limited, and student selection was based on entrance examinations or aptitude tests. Soon there were more upper-secondary school graduates than available places in universities (Nevala, 1999: 44-46). The expansion of the field of HE was aimed at providing equal opportunities for everyone to participate in university formation regardless of one's social background. Social equality was also supported by financial aid and the possibility of a study loan for living expenses offered by the Finnish government (ibid. 53-54).

There are no traditional elite universities, but the divisions to more and less elitist education can rather be conceived through differences between disciplines. The so-called status disciplines in the Finnish context are medicine, law and economics. The selection of the new students is mostly based on matriculation examination, entrance examination or, very often, a combination of these two. The decisions about the selection procedures are under the control of the HE institutions and are therefore institution and discipline centred. The competition is harsh, as the number of applicants is still multiple in relation to the available study positions (Nori, 2011). For example, in status disciplines of law and medicine, with the highest number of applicants in relation to available positions in most disciplines, the University of Helsinki in 2017 had 1,477 applicants for medicine (providing 112 study-positions, pharmacy and veterinary education excluded) and 2,449 for law (providing 200 positions) in Finnish-speaking programmes (University of Helsinki, 2017), resulting in acceptance rates of 13.2 per cent for medicine, and 12.2 per cent for law. As the acceptance rates are low, this causes a space of uncertainty among the candidates.

The entrance examination-based system has been applied in order to promote equality of opportunity, since getting admitted is officially based on the applicant's success in the exam and not dependent on earlier studyperformances or certain degrees (as is the case in the UK, discussed in the next chapter). The system has been seen to offer a second chance to those who have graduated from upper secondary school with poor grades, those applying with a vocational secondary education degree and those wishing to get admitted at a later age (Ministry of Education and Culture, 2016b). The current system makes HE in principle accessible to individuals with all kinds of backgrounds. However, even historically the admitted students in status disciplines have come from higher socio-economic backgrounds than HE students in general in Finland (Nevala, 1999: 200). Recently it has been suggested that by the year 2018 the system of student selections 
should be reformed so that the entrance examinations demanding applicants' long preparation would be removed and more emphasis in the selection would be given to the grades of the matriculation diploma (Ministry of Education and Culture, 2016b). This puts the groups mentioned earlier in an unforeseen and potentially distinct position in the application process.

The highly selective entrance examinations construct a space for uncertainty within the tuition-free system of HE. One notable device that mediates the choice of HE (see van Zanten \& Legavre, 2014) is the private tutoring education market of preparatory courses. The courses are mainly run by private companies and are organised in the biggest Finnish cities. Preparatory courses are commonly used among the candidates, especially when applying to status disciplines such as medicine and law (Kosunen et al., 2015). To pass an entrance exam an applicant has to possess the knowledge and skills based on the specific exam material indicated annually by universities. On the preparatory courses the contents of the entrance examination books are being handled intensively with guidance.

The role of the preparatory courses in a process of applying to HE in Finland has been examined only in a few studies (e.g. Räisänen et al., 2014; Kosunen et al., 2015; Ahola et al., 2016; Ahtiainen, 2017; Töyrylä, 2017), and the topic is still rather unexamined. When considering the private preparatory courses from the perspective of time required and economic investment to be made, attending a preparatory course requires investing both of the two. The prices of preparatory course (with contact teaching) are known to vary in medicine between 500 and 6,500 euros and in law between 100 and 2,500 euros. The courses in medicine are the most expensive of all provided courses, and the courses in law are also fairly expensive, with a large variety of course type and price. (Kosunen et al., 2015.) In a study investigating reasons of attending a preparatory course (Ahola et al., 2016) it was discovered that half of those who decided not to take a course explained that their participation was not possible due to economic reasons. The attendants of the preparatory courses especially in medicine and law were most likely to be off-springs of parents with a high socio-economic status. (ibid.), which indicates that private tutoring is most commonly exploited by the group of candidates who come from affluent back-grounds and comprise higher cultural capital to start with.

\section{The study}

The study focuses upon applicants ( $N=17$ ) who attended a preparatory course in either law or medicine arranged by a private preparatory course company. Sixteen of the interviews were individual interviews, and one was conducted as a pair interview. Twelve of the interviewees applied for medical studies and six for law. This majoring subject is indicated in the extracts with the first letter of the name of the interviewee (L 
for law, like Linda, and $\mathrm{M}$ for medicine, like Matilda). The interviewees participated in preparatory courses organised by two different companies in Helsinki and applied to different universities around Finland. Seventeen had a degree from academic upper secondary education and one from vocational secondary education, which both provide eligibility of accessing HE. Twelve were female and six male, and their age range varied from 19 to 35 years. Eight of them covered the costs of the course fee totally or partly by themselves, and 10 financed the costs with external support such as parents, relatives or another party. During the preparatory course, 11 interviewees had no actual residential costs, as they were able to stay for example at their parents' house (in Finland youngsters often move on their own at age 18). One of the interviewees covered living costs during the course by working, others with savings or financial help from external parties. All our interviewees were classified as belonging to different fractions of the middle class based on their parents' educational and professional background (income was not discussed in the interviews) ( Table 10.1). This definition of social class and the two fractions of the middle class were constructed for analytical purposes by us as researchers and were not discussed as matters of class belonging in the interviews.

Table 1. Social class background and gender of the interviewees $(\mathrm{N}=17)$

\begin{tabular}{|c|c|c|}
\hline Family background & Male & Female \\
\hline Upper middle class & 4 & 6 \\
\hline Lower middle class & 2 & 5 \\
\hline
\end{tabular}

Duration of the interviews varied from 30 minutes to 75 minutes. The interviews followed the structure of the thematic interview frame drawn up in advance, but there was also space for fl exibility and the narrations of the interviewees. The interviewees and the interviewers (Ahtiainen \& Töyrylä, born 1990 and 1988) belong approximately to the same age group, which may have affected the relaxed interaction in the interview situations. To some extent the interviewees might have assumed that there was shared knowledge between them about applying to university and attending a preparatory course. The interviews were analytically categorised and thematised in line with the research task focusing on the discourses surrounding the topics of necessity of buying private tutoring as a part of the preparation and the role of economic capital in the process. Bourdieu's $(1984,1996)$ forms of capital and their different transformations were particularly analysed from the material. 


\section{Social construction of the need for preparatory courses}

All the interviewees had decided for one reason or another to participate on a preparatory course as a part of their preparation to the entrance examinations in law or medicine. In the interviews one of the main issues discussed was the perceived urgent need of participating in a preparatory course when apply- ing to these status disciplines. The inevitability of attending a course was not explicitly discussed in anything other than hypothetical ways. Not attending a course was described as a matter of 'imagined' or 'idealised' others and it was not considered an option for oneself.

It has been the thought, kind of, that law school, business school and med school are such places, where you nearly need to take a prep course to get it that it's a bit ... I don't know if it is just marketing or what ((laughs)).

(Leila, 20, lower middle class, applying 2 nd time, on a prep course 2 nd time)

If you want to get into med school or become a lawyer, you have to take a prep course. (Maria, upper middle class, age 35, applying 1st time, on a prep course 1st time)

The preparatory courses are officially not attached to universities or their admission processes. The university staff is prohibited from having any connections to the private market of preparatory courses, and the knowledge-base of the pro- vided training on the courses is based on experiences of the entrance examinations over the previous years. This obviously rests on the fact that universities seem to test similar things in similar ways year after year. The courses are used to a different extent across disciplines, but for students admitted to the highly selective subjects of law and medicine, the national averages, in terms of students who undertook a preparatory course, are approximately as high as 80 per cent (Kosunen et al., 2017). However, it was hard to track, from where exactly the necessity of the preparatory course originally sprouted. It was evident that the space of competition was difficult to grasp, but the competitiveness of it was acknowledged, as in the following quotation of applicant applying to a less competitive institution:

INTERVIEWER: So do you think that the applicants [to law school] in Turku [University] and Helsinki [University] differ?

I don't think so. Or maybe the differences are not that bi- ... Maybe to Helsinki there will be more such candidates, whom trust the fact that they will get admitted to a tougher school, that they are more self-confi dent.

(Leila, lower middle class, age 20, applying 2 nd time, on a prep course 2 nd time)

The space of competition (Taylor, 2002) and the social space of educational choice (see Kosunen, 2016) were evaluated in terms of competitive hierarchies between candidates and symbolic hierarchies between institutions (this operates in different ways in different systems, and interesting comparisons can be drawn 
by considering the case of France and the UK presented in this volume). The symbolic positions of the different institutions were discussed in several inter- views mainly as matters of reputation, as the actual diplomas derived from all different public universities in Finland should technically have a similar value at the labour market (even if that might not be the case in reality). However, the 'market awareness' (Reay et al., 2005: 52) was existent and the hierarchies across HEls were acknowledged, as the applicants were able to evaluate which were the toughest universities in terms of difficulty of admission. In comparison to being aware of institutional hierarchies, positioning themselves in relation to the other applicants on the field was a harder task.

The urge to attend a preparatory course in order to receive support in the admission was constructed discursively as a strategy of enhancing one's chances of getting admitted over other candidates. The perceived profi t was constructed mainly in relation to 'naturally' better students than they themselves (imagined geniuses), due to which the course was considered necessary. Previous studies (Kosunen \& Haltia, in press) have shown that the marketing strategies targeting the prospective customers are actually trying to attract all kinds of applicants. However, the construction of the 'imagined others' contributing to the need of buying a course was constructed on the basis of those candidates who do not attend a course. There was a paradox in description of the ones who did not attend a course: they were perceived as the best applicants, who do not need a course and will still get admitted, and simultaneously as applicants who are less 'motivated' and less 'serious' about trying to get admitted than those attend- ing a course (ibid.). Neither of these positions is an easy position for anyone to take in a time of high competition and uncertainty over the admission. In the discourse of the applicants in this study, their own inferior position to the 'best' candidates got emphasised and was applied as a core explanation why they considered the course necessary for themselves.

Well in fact I thought that yes, for me it is somehow compulsory [to take a prep course]. Especially, as I started from the scratch, so I thought that I would get a lot from the course in comparison to some, who have already read a lot in advance and gone through all [relevant] courses in high school.

(Mona, lower middle class, age 22, applying 2 nd time, on a prep course 2 nd time)

I'm not the golden star among others, who shines so bright that will get past everyone else, but most likely belong to those [who need a course] because I don't usually stand working that much that I would be the one [the star].

(Martin, lower middle class, age 21 , applying 2 nd time, on a prep course 1 st time) 
Especially Martin could have been considered as one of the most prominent candidates for the program when considering his previous excellent performance in natural sciences in high school. However, his own perception in this time of uncertainty was that more training would be required, as the uncertainty of the admission was not compensated with his earlier academic success. This then raises the question, who according to this discourse would not need the preparatory course if he does? In the interviews, the social hierarchies between the candidates were presented in a form in which the ones holding the trump cards (Bourdieu, 1984) in the game were the ones who had prepared best prior to the examination. The description was twofold: the best candidates were the ones 'naturally' more 'talented' than the others (expectedly high cul- tural capital), and their only competent competitors were those, who gained the needed knowledge and skills (cultural capital through academic social capital) through private tutoring on a preparatory course. The possibility of preparing for the exam individually was considered insufficient among the interviewees in the preparation especially to medical studies:

I would say that there you see that I have a clear cutting-edge in rela- tion to those, who did not take that course. Because then it'll be like that the ones who have not gone through the course, they have come to put together the puzzles [answering poorly to the diffi cult tasks in the entrance examination], but I don't need to, as I'm over it already, as those [tasks] have been well taught.

(Martin, lower middle class, age 21, applying 2nd time, on a prep course 1st time)

In some of the cases, the practice of middle-class schooling (Ball, 2003) was evident: Matilda and Matt received parental support verbally and socially as well as financially. The question was not whether they would apply but rather when they would apply to HE and how. The planning for HE had been long term, which can be interpreted as a kind of a middle-class praxis (Reay et al., 2005).

It was actually their [the parents'] idea to put [me] to this preparatory course, as I said that, three month-time, I could read, but next year I'll apply properly, as I have one year to read. Then they [said] that if you try, try properly, and then you take a prep course, that it is sensible to try at maximum and take a prep course, that that's where you get extra help then.

(Matt, upper middle class, age 19, applying 1st time, on a prep course 1st time)

Well in principle I would consider it fairly important that [my] parents have always, from the times a was small, helped me with homework and been supportive. . . that you cannot apply so that [you think] that you can't do it. That if you lack that [attitude]. And you've never done your home- work properly, maybe then you can't [apply].

(Matilda, upper middle class, age 24, applying 2nd time, on a prep course 2 nd time)

Even if the middle-class discourse on the admission was mainly about the advantages they had in relation to some other candidates. Also the over- generational pressure of occupying the positions existed. Thereby the 
idea of aiming to get admitted was not interpreted only as a privilege, but also as a perceived necessity, which was implicitly related to processes of reproduction of social positions.

There's a lot of those people whose parents are in the same business and they say they have a lot of pressure, as their parents are in the same branch, to get into law school at first try. (Lisa, upper middle class, age 20, applying for the 2 nd time, on a prep course 1st time)

The applicants in general presented the course participation as a form of creating certainty in an uncertain time but also as a personal development process, where cognitively and socially their 'full potential' would be fostered. The importance of the course as a social unit, providing access to scarce resources (information about answering well in the exams) and creating routines and discipline in the preparation process, was acknowledged.

Additionally, the experience of these applicants' friends, who had attended preparatory courses and managed to get admitted, and the related peer-pressure of getting admitted, actually created new social norms in the admission process among the candidates. Attending a preparatory course had become a thing 'people like us do' (see Reay et al., 2009: 1110) among these middle-class youngsters. However, the social pressure of attending a course was (even paradoxically) constructed through observing those who were admitted without a prep course: this logic functions as a self-fulfilling prophecy, as the rumour of a small number of applicants preparing and getting accepted on their own was considered an exception. None of these applicants claimed they knew anyone who had gotten admitted without a preparatory course. The recent quantitative findings of admitted students indicate that there is a fair reason for this perception (see Kosunen et al., 2017), as in law and medicine more than 75 per cent of those admitted in these disciplines had participated on a course at least once.

I have, oh well (pause), all my friends are studying, and I want to get for-ward here, and then it is just that if the intake [to med school] of those without a prep course is such an infinitesimal percentage, then you could practically say that you have to take a prep course to get in. (Martin, lower middle class, age 21 , applying 2 nd time, on a prep course 1 st time)

Additionally, the question of the amount and form of the embedded cultural capital among those who did not feel the urge of buying private tutoring and were still successful in the entrance examination should be raised. Partly it was related to the previous success in secondary education (mainly institutionalised cultural capital), partly to the perceived family traditions and norms (embodied cultural capital) (Bourdieu, 1984).

Well I have a very stereotypical fi gure, where I don't think I would fi $t$ in myself, but [the admitted students] are such that have written like fi ve straight As and one A-, and as I have defi nitely not written fi ve As... And then those really talented, who have a eidetic memory, 
and as they've once read a book they'll know it by heart.. So it's pretty stereotypical that good students apply. Geniuses.

(Lisa, upper middle class, age 20, applying for the 2 nd time, on a prep course 1 st time)

It was evident that the actual admission process required a lot of different forms of capital (Bourdieu, 1984) from the applicants, such as social networks whom would support in the application process (e.g. doing baby-sitting or providing general social support), prior skills in different topics (such as in mathematics in medicine: the access even to the preparatory courses was denied if their knowledge in mathematics was not sufficient to start with) and actual money to attend the course (paying for the fees as well as covering the living-costs during the course). Several transformations from one form of capital to another took place during the whole transition. The most evident of these transformations was the economic capital invested in the course and the expected skills as a form of cultural capital that were expected from the course after the pedagogical intervention.

However, none of the required resources or forms of capital were discussed as matter of interest in terms of gaining access to HE. The differences in the potential success in the competition, regardless of the notions regarding the required forms of cultural and social capital, were reduced into a discussion mainly around the psychological features of the different applicants, especially that of motivation and hard work. The myth of meritocracy (Reay et al., 2009), in which merit is defined as a combination of talent and effort independent of family resources (van Zanten \& Maxwell, 2015), was evident in the interview material of these middleclass applicants. This was a way of avoiding the discussion around social inequalities in terms of cultural capital, as well as the most evident difference in access to economic resources to be invested in the admission. In fact, the different starting points and possible inequalities were not clearly perceived as long as money was not discussed explicitly.

It is also that what kind of a motivation you have, and what kind of effort you make. But I would not say that it's a matter of [social] starting points, but [rather] that it is the personal motivation and like what kind of potential someone has to use and how they use it. (Martin, lower middle class, age 21, applying 2nd time, on a prep course 1st time)

I started thinking that hey, what if I applied for law school, and then I thought I can't ... that it just wouldn't, that I just couldn't. But then I found out about things and then I was like that people do get in, it is possible to get in. If you have motivation and if you want, you can get in, that it's possible. And now that I got the idea and I'm applying to law school, I haven't got rid of the thought, and probably won't.

(Laura, lower middle class, age 21, applying for the 1st time, on a prep course for the 1st time) 
In this interpretation it needs to be questioned how much misrecognition of cultural capital is embedded. Are the geniuses, who could make it without a course, actually the ones whose parents have a relevant social and educational background that, in the ways of transmitting cultural capital within a family, are profi ting their offspring? If this is the case, this logic does not concern those from the lower social backgrounds. In case these are the only two competitive options for accessing status disciplines in Finnish HE, either by reading at home and receiving the 'right' kind of support from the family or attending a preparatory course, and if the courses are non-accessible to many due to high course fees, there is a misrecognition of economic inequality in the admission process.

\section{Role of economic capital in the admission process: who can afford applying for HE?}

Economic capital as a factor contributing to the participation in $\mathrm{HE}$ in Finland has been widely discussed in terms of tuition-free education, student support and study loan during the studies. The participation on a preparatory course is not considered studying, as it does not result in official records or belong to the educational system: thereby no support is provided for preparatory course participants, and tuition fees are to be freely gathered, as it is not a part of the official education system but private shadow education. Additionally, as the courses concern a phase between secondary and tertiary education, the discussion around finance is usually not discussed in the sphere of education but as social policy. Usually the courses are financed either by parental financial support, savings or by working simultaneously (or sometimes all of them). Also, the funding base of the course is related to the social background, where the applicants from lower social backgrounds buy cheaper courses and finance them by working simultaneously, while higher social classes usually receive parental support for more expensive and extensive courses (Kosunen et al., 2017). As the prices in preparatory courses especially in medicine and law are among the most expensive, the question of who can afford them arises:

They say that it is tuition-free to study in Finland and so, but I'm starting to feel that especially in those, where it's hard to get in anyhow, like law school and med school, there I start feeling the difference. That if you don't take a preparatory course, do you end up lacking a lot of trivia about the exam and all, if you don't take the course. And if that's the reason lof not getting admitted], that would not be equitable, that everyone can get in if they just want, as not everyone can afford the course.

(Mona, lower middle class, age 22, applying 2 nd time, on a prep course 2 nd time)

And then those less-well-off can't afford the courses ... and then at univer- sities the books and all are fairly expensive, that if you really don't live with your parents and you have no... capital anywhere... it's like you can't really succeed in the same way.

(Lea, lower middle class age 20, applying for the 2nd time, on a prep course for the 2 nd time) 
Given that the active course participation and the preparation required for the successful admission are dependent on the time available, the course fees along with the emerging costs of living may construct an unbearable need for economic capital for some applicants. However, the discourse around the role of available economic capital turns back to motivation and capability of risk-taking:

Oh well. It's hard to say. [The price], it's quite a lot of money, but also that is a thing that if you have enough motivation, you spend some time on it, you get the money together for yourself... And then, I don't believe it's an obstacle but rather a roadblock to someone.

(Martin, lower middle class, age 21, applying 2 nd time, on a prep course 1st time)

The price might, however, turn out to be an obstacle for the whole application process in this discursive space:

Well the preparatory course is probably the biggest [financial] step, for all, and when you get admitted then the [student support] probably covers pretty well the studies, but well, the preparatory course [fee] is the biggest step and thereby many might not apply at all, as they experience that it is needed.

(Lea, lower middle class, age 20, applying for the 2 nd time, on a prep course for the 2 nd time)

Lea puts forward a major issue regarding the economic capital invested in the HE admission: in case the preparatory courses become inevitable in the process and the prices remain high, this might bring about a new form of social (self-) exclusion, as some of the prospective candidates may not apply in the fi rst place, as they would not believe in their actual chances of getting admitted. The most interesting part concerning the role of economic capital was the repetitive contrasting to tuition fees in private universities in other countries. The logic was that the Finnish HE-system has to be equal, as it is tuition free, and no other forms of economic inequalities could actually be thoroughly acknowledged among these youngsters.

Those [less-well-off] have just different starting points, but pretty well the same possibility exists ... as you can't buy anything [private university education]. Or well, you can buy all these courses and so on, but if you're good, you get in.

(Matt, upper middle class, age 19, applying 1st time, on a prep course 1st time)

The economic capital used on a preparatory course was interpreted as an economic investment, which will pay itself back in later professional phases enabled by the qualification that it helped to secure. For the most affluent applicants, the money, as such, was not a question: rather, using private economic capital for buying the tutoring service was considered a valuable and profi table investment. The consumerist discourse around 
education as a private investment, a way of transforming economic capital into different kinds of cultural capital in the long run, was discussed:

It might get expensive, but when I become a doctor, it's ok, because in the future I will make money. So the money comes back to me, it does not disappear from me. It's not a small money, but this course gives me a lot of opportunities and I get quickly further with it . . . earlier to university, earlier out of school and earlier to working life.

(Maria, upper middle class, age 35, applying 1st time, on a prep course 1st time)

I feel it's worth it. If with that I get admitted. ... And when I start working as a doctor it's not impossible to pay that back; then I can pay the money back to my [relative].

(Mona, lower middle class, age 22 , applying 2 nd time, on a prep course 2 nd time)

Given the tuition-free nature of the Finnish HE, saving money for studying has not been really known as a common practice, but as our following examples show, might be becoming or have become one already. Some of the applicants discussed how they are using their saving into buying the preparatory course in order to enter the studies.

I have some possessions or capital that my parents have gathered me.. it's been saved for me for my studies, so I don't feel it's money away from any- thing else, as it has been saved for this purpose...

(Lea, lower middle class, age 20, applying for the 2 nd time, on a prep course for the 2 nd time)

Back then, when I took [the savings] out of my saving account... which is meant to help me out with getting a mortgage or so. Then I thought that this is ((pause)) this is kind of the same. That this is an investment in the future.

(Max, lower middle class, age 20, applying 3rd time, on a prep course 2nd time)

Regarding the transformation of capital (Bourdieu, 1984, 1996), this was an intended procedure in which the cultural capital (in the form of knowledge) led to saving and investing economic capital into private tutoring, which was supposed to bring skills (trump cards) in the examination and thereby result in a university place and a degree from a status discipline (institutionalised cultural capital). When entering the labour market, this institutionalised form of cultural capital will translate into economic capital, after which the original investment could be paid back.

Even if the educational inequalities are relatively subtle in the Finnish context in relation to some more stratifi ed others, the social inequalities in the educational journey to HE seem to persist, even if in a more hidden form. The social positions the applicants' families have and the accumulation of capital seem to push the offspring of higher social classes to further studies, even in the same status disciplines, much stronger that 
those from lower-social-class back- grounds. Paradoxically, for those from the lower social classes who can afford a course, it might actually function as a trump card in the admission.

\section{Discussion}

The analysis revealed three different groups of candidates with different relationships with preparatory courses and perceived competitiveness in the competition over the university places, which as a finding is supported by previous studies dealing with the marketing practices of the preparatory courses (Kosunen \& Haltia, in press). The three distinct groups of applicants were constructed in the discourse of this one group of candidates, who all were attending preparatory courses: the 'naturally talented', the 'motivated' and the 'non-motivated'. They themselves seemed to belong to the group of so-called motivated that were in the need of external support in the admission-process. The reasoning behind this division was strongly bound to the need of attending a preparatory course and to the goal of being successful in the competition over places. Only the first two groups were considered competitive. The imagined group of the 'naturally talented' was perceived as high in cultural and social capital by many means (such as being 'geniuses' with visual memory, for example, as well as hypothetically coming from higher social backgrounds and having received the support from their parents, who themselves would be working in the branches of law or medicine), and thereby their economic investment in the form of buying a preparatory course was not required. However, in these status disciplines this group remained hypothetical, as even the best students from the upper middle class would not consider themselves as belonging to this category.

The group of 'motivated' exchanged economic capital into cultural on preparatory courses. They aimed to gain embodied cultural capital (e.g. skills in ways of answering the entrance examination questions with the 'right' style) through private tutoring, which would be translated into success in the admission and then later transformed into institutional cultural capital in the studies. After finishing with the studies, the institutionalised cultural capital in the form of a juridical or a medical degree, along with the social capital derived through he shared university experience, would result in high employability and in high economic returns, salaries. Thereby the idea of transforming different forms of capital into each other (cultural and economic into a different kind of cultural capital and then eventually back to economic) was a long-term plan for the offspring of the middle classes. Obviously, this sort of planning would require cultural, social and economic capital to start with. A pocketful of money might not have been enough as it comes to the immediate costs during the preparation time prior to the HE-admission. 
The roles of capital were misrecognised (Bourdieu, 1986), especially when discussing the third group, perceived as non-motivated and not really competitive. Perceptions of this group reduced the role of different forms of capital into individual psychological features, such as lack of motivation. This follows a neoliberal argumentation over individuals' freedom and responsibilities, as if no social or structural inequalities existed. The economic thresholds that would prevent some of the applicants from attending a preparatory course would also place them discursively in the third group of non-motivated applicants, which was positioned in the discourse as a non-competitive group. This as such would not officially prevent anyone from applying to status disciplines in Finnish $\mathrm{HE}$, but this might increase the likelihood of not trying among those who, due to economic, reasons could not attend a course, and due to socially constructed reasons believe it would be necessary for them. Following this logic, the socially constructed need of participating in private tutoring as a part of the preparation to the entrance examinations to status disciplines might create a pattern of de facto social closure, which again would reinforce the elitist nature of those disciplines.

The construction of the discourse around actually competitive ways of applying to status disciplines seems to include a social class bias, enable a pattern of social exclusion and possibly a forum for 'voluntary selfexclusion' from lower social backgrounds (as the means available in the admission are not considered discursively adequate) but is being misrecognised due to the strong psychological discourse penetrating the discussion. This neoliberal psychologisation of the resources required in the admission puts the responsibility on an individual applicant and dismisses the argument concerning economic inequalities, as it is reduced into a matter of sufficient motivation and sacrifice. The role of restricted access to economic capital as a factor influencing the successful admission to Finnish tuition-free higher education would require further analysis. 


\section{References}

Ahola, S. (1995). Eliitin yliopistosta massojen korkeakoulutukseen. Korkeakoulutuksen muuttuva asema yhteiskunnallisen valikoinnin järjestelmänä. Turku: University of Turku.

Ahola, S., Asplund, R., and Vanhala, P. (2016). Valmennuskurssit - välttämätön paha vai jotain muuta? - ketkä osallistuvat valmennuskurssille ja miksi? Tiedepolitiikka, 4, 61-67.

Ahtiainen, H. (2017). Valmennuskurssit ja koulutusmahdollisuuksien rakentuminen lääketieteen opintoihin hakeutuvien puheessa, Master's Thesis, University of Helsinki.

Ball, S. J. (2003). Class Strategies and the Education Market: The Middle Classes and Social Advantage. London: Routledge.

Bourdieu, P. (1984). Distinction: A Social Critique of the Judgement of Taste. Cambridge: Harvard University Press.

Bourdieu, P. (1985). The social space and the genesis of groups. Theory and Society, 14, 723-744.

Bourdieu, P. (1986). The forms of capital, in: J. G. Richardsson (ed.) Handbook of Theory and Research for the Sociology of Education. New York: Greenwood Press.

Bourdieu, P. (1996). The State Nobility. Cambridge: Polity Press.

Bourdieu, P., and Passeron, J. C. (1990). Reproduction in Education, Society and Culture. London: Sage Publications.

Jauhiainen, A., and Nori, H. (2017). Puurtajat, Statuksen korottajat ja Koulutuspääoman uusintajat: Tohtoriopiskelijat ja heidän taustansa suomalaisella yliopistokentällä. Kasvatus, 48, 80-95.

Käyhkö, M. (2017). Keinumista kahden maailman välissä. Työläistaustaiset naiset, yliopisto-opiskelu ja muuttuva suhde kotimaailmaan. Sosiologia, 54, 6-22.

Kivinen, O., Hedman, J., and Kaipainen, P. (2012). Koulutusmahdollisuuksien yhdenvertaisuus Suomessa. Eriarvoisuuden uudet ja vanhat muodot. Yhteiskuntapolitiikka, 77, 559-566. Kosunen, S. (2016). Families and the Social Space of School Choice. Unigrafia: University of Helsinki.

Kosunen, S., Haltia, N., and Jokila, S. (2015). Valmennuskurssit ja mahdollisuuksien tasa-arvo yliopistokoulutukseen hakeutumisessa. Kasvatus, 46, 334-348.

Kosunen, S., Haltia, N., Saari, J., Jokila, S., and Halmkrona, E. (2017). Preparatory Courses as Shadow Education in Access to Higher Education in Finland. Paper presented in CHER 30th Annual conference. Retrieved 28-30 August 2017, Jyväskylä, Finland.

Kosunen, S., and Haltia, N. (in press)). Valmennuskurssit ja koulutuskuluttajuus. Sosiologia.

Ministry of Education and Culture. (2016a). University Administration and Finance. Retrieved from www.minedu.fi /OPM/Koulutus/yliopistokoulutus/hallinto_ohjaus_ja_rahoitus/?lang=en (accessed 14 November 2016). 
Ministry of Education and Culture. (2016b). Valmiina valintoihin. Ylioppilastutkinnon parempi hyödyntäminen korkeakoulujen opiskelijavalinnoissa. Opetus - ja kulttuuriministeriön julkaisuja, 37.

Nevala, A. (1999). Korkeakoulutuksen kasvu, lohkoutuminen ja eriarvoisuus Suomessa. Helsinki: Suomen Historiallinen Seura.

Nori, H. (2011). Keille yliopiston portit avautuvat? Tutkimus suomalaisiin yliopistoihin ja eri tiet- eenaloille valikoitumisesta 2000 - luvun alussa. Turku: University of Turku.

Räisänen, M., Kuitunen, M., Partanen, L., and Österlund, P. (2014). Lääketieteelliseen koulutukseen valikoituminen. Yliopistopedagogiikka, 21, 88-92.

Reay, D. (2005). Surviving in dangerous places: Working-class women, women's studies and higher education. Women's Studies International Forum, 21, 11-19.

Reay, D., Crozier, G., and Clayton, J. (2009). 'Strangers in Paradise'? Working-class students in elite universities. Sociology, 43, 1103-1121.

Reay, D., David, M. E., and Ball, S. (2005). Degrees of Choice: Class, Race and Gender in Higher Education. Sterling: Trentham Books.

Taylor, C. M. (2002). Geography of the 'New' Education Market: Secondary School Choice in England and Wales. Aldershot: Ashgate.

Töyrylä, M. (2017). Diskurssianalyyttinen tutkimus oikeustieteen opintoihin hakemisen kilpailusta ja hakijoiden valmennuskurssille osallistumisesta, Master's Thesis, University of Helsinki. University of Helsinki. (2017). The Amount of Applicants in University of Helsinki in Spring 2017. Online. Retrieved from www.helsinki.fi/sites/default/files/atoms/files/1_kandiohjelmiin-_ hakeneet-yhteishaussa-2017.pdf (accessed 10 April 2017).

Van Zanten, A. (2015). Les inégalités d'accès à l'enseignement supérieur. Quel rôle joue le lycée d'origine des futurs étudiants? Regards croisés sur l'économie, 16, 80-92.

Van Zanten, A., and Legavre, A. (2014). Engineering access to higher education through higher education fairs, in: G. Goastellec and F. Picard (eds.) Higher Education in Societies. Rotterdam: SensePublishers.

Van Zanten, A., and Maxwell, C. (2015). Elite education and the State in France: Durable ties and new challenges. British Journal of Sociology of Education, 36, 71-94. 